\title{
The 'Banking Dialogue' as a model to improve parliamentary involvement in the Monetary Dialogue?
}

Citation for published version (APA):

Fromage, D., \& Ibrido, R. (2018). The 'Banking Dialogue' as a model to improve parliamentary involvement in the Monetary Dialogue? Journal of European Integration, 40(3), 295-308. https://doi.org/10.1080/07036337.2018.1450406

Document status and date:

Published: 01/01/2018

DOI:

10.1080/07036337.2018.1450406

\section{Please check the document version of this publication:}

- A submitted manuscript is the version of the article upon submission and before peer-review. There can be important differences between the submitted version and the official published version of record.

People interested in the research are advised to contact the author for the final version of the publication, or visit the DOI to the publisher's website.

- The final author version and the galley proof are versions of the publication after peer review.

- The final published version features the final layout of the paper including the volume, issue and page numbers.

Link to publication

\footnotetext{
General rights rights.

- You may freely distribute the URL identifying the publication in the public portal. please follow below link for the End User Agreement:

www.umlib.nl/taverne-license

Take down policy

If you believe that this document breaches copyright please contact us at:

repository@maastrichtuniversity.nl

providing details and we will investigate your claim.
}

Copyright and moral rights for the publications made accessible in the public portal are retained by the authors and/or other copyright owners and it is a condition of accessing publications that users recognise and abide by the legal requirements associated with these

- Users may download and print one copy of any publication from the public portal for the purpose of private study or research.

- You may not further distribute the material or use it for any profit-making activity or commercial gain

If the publication is distributed under the terms of Article $25 \mathrm{fa}$ of the Dutch Copyright Act, indicated by the "Taverne" license above, 


\section{The 'Banking Dialogue' as a model to improve parliamentary involvement in the Monetary Dialogue?}

\section{Diane Fromage \& Renato Ibrido}

To cite this article: Diane Fromage \& Renato Ibrido (2018) The 'Banking Dialogue' as a model to improve parliamentary involvement in the Monetary Dialogue?, Journal of European Integration, 40:3, 295-308, DOI: $10.1080 / 07036337.2018 .1450406$

To link to this article: https://doi.org/10.1080/07036337.2018.1450406
(2) 2018 The Author(s). Published by Informa UK Limited, trading as Taylor \& Francis Group
册 Published online: 31 May 2018.

Submit your article to this journal

Q View related articles $₫$

View Crossmark data $\asymp$ 


\title{
The 'Banking Dialogue' as a model to improve parliamentary involvement in the Monetary Dialogue?**
}

\author{
Diane Fromage $^{a}$ and Renato Ibrido $^{b}$

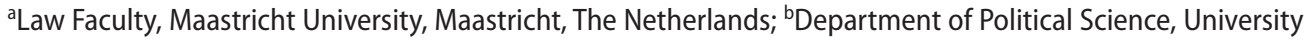 \\ LUISS Guido Carli, Rome, Italy
}

\begin{abstract}
The newly established European Banking Union has introduced a unique accountability framework of the European Central Bank vis-à-vis the European Parliament (EP), but also vis-à-vis national parliaments, in the form of Banking Dialogue. The ECB was thus far held to account for its monetary policy actions by the EP in the framework of the long-existing Monetary Dialogue. However, some shortcomings have become apparent in this procedure, especially with the economic crisis. Beyond this, the recent attribution of new competences to the ECB calls for a reflection as to the accountability mechanisms in place to control its actions. Based on an empirical and normative analysis of both types of dialogues, we contend that the Banking Dialogue could serve as a model to reform the Monetary Dialogue to enhance the legitimacy of the ECB's actions and of the EU as a whole.
\end{abstract}

\section{KEYWORDS}

Monetary Dialogue; Banking Union; European Central

Bank; accountability; national parliaments; European Parliament

\section{Introduction}

In his speech in front of the Industrie- und Handelskammer of Berlin, Carl Schmitt identified the Reichsbank of the Weimar Republic as the paradigmatic case of neutrale Grösse ('neutral power') (Schmitt 1958). Schmitt conceived of the Reichsbank as a technocratic institution called to make political decisions in place of political bodies but which is destined to be 'captured' by political forces in the long run. Eight decades after Carl Schmitt expressed those concerns in Berlin, the thorny question of central banks"neutral powers' has re-emerged. Indeed, the resort by the European Central Bank (ECB) to unconventional monetary policies - especially after the Gauweiler decision of the European Court of Justice in which the Court deemed these policies to be in line with the Treaties (Hinarejos, 2015, 563 ss) - as well as the creation of the (first) supervisory pillar of the Banking Union have drawn attention to the'enlargement' of the ECB's functions in times of crisis. The ECB is now undoubtedly a key actor in the European Union's (EU) economic governance. It is deemed to act 'to keep the euro stable and monetary policy healthy' (Bovens and Curtin 2016, 190) and was hence led to play a crucial role during the economic and financial crisis. Its role was not only enhanced in practice and its 
since the increased effectiveness of the accountability mechanisms vis-à-vis the ECB may contribute to the EU's throughput legitimacy. In this framework, parliaments and governments are arguably both in a weak position towards the independent ECB. Nevertheless, parliaments may contribute to increase democratic legitimacy by improving transparency and by holding the ECB to account even if, as detailed below, this is an accountability of a special kind.

It is worth noting that the Banking Dialogue also involves a direct relationship between a newly established EU agency, the Single Resolution Board (SRB), and the EP, as well as between the SRB and national parliaments. This agency is in charge of banking resolution, which is the second pillar of the Banking Union. Given that the focus of this article is set on the relationship between the ECB and the EP however, the procedures developed in the framework of the SRM - which are fairly similar to those existing in the framework of the SSM - are not examined here. Furthermore, the question whether the EP (and national parliaments) has the ability and the willingness to hold the ECB to account for its action is a question that remains out of the scope of this article as our focus is mostly normative and hence examines whether the EP has the necessary instruments to be actively involved. It is nevertheless hard to imagine that any other institution having the same democratic legitimacy as national and European legislatures would be better able and placed to hold the ECB to account.

This article is structured as follows: we first recall the specificities of the accountability mechanisms that can be developed towards the ECB given its independent nature. Subsequently, we examine the Monetary Dialogue and how it has functioned in its over twenty years of existence, after which we turn to the newly created Banking Dialogue. We conclude with an assessment of the possibilities of spill over effects between the new and the older mechanisms.

The issue of the ECB's democratic accountability has arguably been analysed by a vast literature, especially by political scientists and economist (inter alia Amtenbrink 1999; Gormley and De Haan 1996; Jančić 2017). By contrast, the constitutional implications of the 'dialogical procedures' which guarantee the EP's and national parliaments' participation in the democratic oversight of the ECB in the new context described above have only been recently introduced and hence have not yet been adequately explored. In particular, a study from a European constitutional law perspective is lacking as the existing literature has focused either solely on the European Parliament (Amtenbrink and Markakis 2017) or has addressed the issue of accountability on a more general level (Curtin 2017) This contribution on the other hand examines the ECB's accountability as one of the core topics of the process of 'constitutional integration' in the EU whereby the ECB increasingly assumes functions traditionally in the realm of national central banks 'competence. Furthermore, especially in the field of the Banking Union where further integration is expected to take place in the near future (European Commission 2017), the issue of the parliamentary oversight over the ECB questions the future of democracy in the EU. The ECB's dual role as the EU's Banking supervisor and as the main responsible for the Eurozone's monetary policy also raises further question as to the reconciliation of both roles - as supervisor and as responsible of the monetary policy - and potential overlaps, which additionally render any external controls more complex. 


\section{Specificities of the ECB's accountability framework}

The independence of central banks is considered a key factor to guarantee low inflation. In this perspective, the maintenance of price stability has been considered as the Grundnorm of the European System of Central Banks (Zilioli and Selmayr 2001, 35-36). Indeed, politicians tend to opt for the costliest policies to secure their re-election instead of favouring sane public finances; they tend to focus on immediate effects instead of pursuing long-terms economic policies. It is with this aim that central banks are made, more or less, independent from other public authority bodies, notably parliaments and governments (Amtenbrink and van Duin 2009, 563-564). In the case of the ECB, Article 130 TFEU specifically protects it from any interference as it states that:

When exercising the powers and carrying out the tasks and duties conferred upon them by the Treaties and the Statute of the ESCB and of the ECB, neither the European Central Bank, nor a national central bank, nor any member of their decision-making bodies shall seek or take instructions from Union institutions, bodies, offices or agencies, from any government of a Member State or from any other body.

Such independence, however, does not prevent the ECB from being accountable for its actions, although this is an accountability of a special kind. Accountability can indeed generally be defined as'a relationship between an actor and a forum, in which the actor has an obligation to explain and to justify his or her conduct, [where] the forum can pose questions and pass judgment, and the actor may face consequences' (Bovens 2007, 117). If this concept of accountability is applied to the ECB, it appears that the last element of this definition is missing: whereas the ECB may have to explain and justify its conduct to, for instance, the EP (and potentially to national parliaments too), which, in turn, can pass judgment, there can never be any immediate binding consequences for the ECB considering its full independence. It follows that the only impact the existing accountability mechanisms can have is a soft one, in the sense that it will be limited to, among others, the possibility for parliamentarians to publicly debate with the ECB and ask questions about its actions.

In case of disagreement, the ECB can pursue its policies and will remain in place; however, the perception citizens (and markets) have of its behavior may be (negatively) affected. By contrast, accountability mechanisms in an ordinary setting would allow the controlling forum -to use Mark Bovens' terminology- to push to the termination of the mandate of the controlled body or request it to amend its policies. The irrevocable nature of the ECB's board hence does not mean that it should not be held accountable for its actions. It solely implies that it is a special kind of accountability that does not necessarily result in the EP not being heard by the ECB. Research has indeed shown that the ECB has been responsive to the EP's input (Eijffinger and Mujagic 2004). Note though that MEPs member of the Committee of economic and monetary affairs (ECON Committee) perceive this otherwise; at least as concerns their impact on the crisis. $55 \%$ of them consider that the Monetary Dialogue has had no impact on the management of the crisis even if the same percentage of MEPs believe the ECB takes their views into account (Collignon 2014, 19).

Amtenbrink (2012, 350f) usefully defines ex ante and ex post instruments of accountability where consequences cannot be taken directly against the institution held accountable. Although these tools are defined in reference to informal international policy-making and law-making actors, their application to the ECB proves pertinent. Ex ante instruments are used before the institution has even started to act in the form of, for instance, the 
establishment of the legal basis or the appointment of the members of the decision-making body of the institution controlled. Ex post instruments allow to sanction the results of the institutions controlled by inter alia changing its legal basis in case of underperformance or by not reappointing board members. As Amtenbrink rightly notes, this might, however, prove difficult as in the 'ECB, [...] the national central bank governors, who participate in the Governing Council (the main policy decision-making organ), can hardly be held accountable for the collective monetary policy decisions of the Bank' (351).

\section{Monetary Dialogue ${ }^{1}$}

Having highlighted the specificities of the ECB's accountability, we may turn to the oldest mechanism put in place with this aim, the Monetary Dialogue. The Monetary Dialogue's legal basis can now be found in Article 284-3 TFEU and its features are detailed in the EP's rules of procedure. It is an integral part of the EU monetary policy upon which the EU has exclusive competence (Article 3-1 c TFEU), which arguably may be one of the reasons why national parliaments were not involved in this framework although they are in the Banking Dialogue. Additionally, the monetary policy is unique and applies across the Eurozone equally whereas the decisions made in the banking sector are taken individually and affect Member States differently, which could explain why national parliaments are only involved in the latter policy. ${ }^{2}$ In fact, a larger role for national parliaments had originally been proposed by former French President Chirac, alongside the creation of an interparliamentary committee suggested by former French President Giscard d'Estaing; the EP nevertheless rejected both proposals (Magnette 2000,333), perhaps in an attempt to secure its own newly acquired rights. As further discussed below, given that Member States are directly impacted by the ECB's monetary policy, there is actually a strong argument in favour of national parliaments being at least informed and able to submit questions to this end to the ECB as it happens in the framework of the Banking Dialogue. For instance, some information rights for the National Parliaments within the monetary policy could find their basis and justification in the principle of mutual sincere cooperation (art. 13-2TEU), which governs the relationships between the European Union and Member States, including in the areas which fall within the EU exclusive competence. The lines between monetary and fiscal policy actions in the ECB's conduct have additionally become increasingly blurred. The fact that the ECB may act in the fiscal domain, which does not belong to the exclusive competences of the EU, again speaks in favour of an increased involvement of national parliaments. Beukers for instance raised the question whether the ECB President should have appeared before the Italian parliament when it agreed to buy Italian government bonds in 2011 (Beukers 2015, 109).

As stated in the introduction, this Dialogue attributes several instruments to the EP. The ECB's annual report on the activities of the ESCB and on the monetary policy shall first be presented by the president of the ECB and a general debate may be held on this same report. An informal procedure following which the report is presented by the ECB vice-president to the ECON Committee on the day of its publication has developed in parallel. This leaves time to the EP to prepare a resolution stating its opinion before the report is presented in its plenary by the ECB's president (Claeys, Hallberg, and Tschekassin 2014, 4). Then the president can address the resolution's important points during his or her presentation. Second, the president of the ECB and the other members of the Executive Board may be heard by the competent EP committee at the EP's or the ECB's request. Such a request is, however, 
not legally binding on the ECB (Amtenbrink and van Duin 2009, 569). Nevertheless, the president of the ECB submits him or herself to four yearly hearings as foreseen by the EP's rules of procedure (rule 126-3). The provisions of the EP's rules of procedure admittedly do not entail any obligation on the ECB; nonetheless, the Central Bank has been eager to exchange with the EP since its creation.

These four yearly exchanges interestingly amount to more than what the EP had requested (and failed to obtain) during the negotiations that preceded the adoption of the Maastricht Treaty. The EP had indeed asked for the president of the ECB to not only present its yearly report, but also appear before the competent committee biannually and whenever important circumstances would so require (European Parliament 1990,6). MEPs may furthermore address written questions to the $E C B$, which also answers in writing. This procedure is spelt out in Article 131 of the EP's rules of procedure. Where the ECB does not answer by the required deadline, the question can be asked directly during the next Monetary Dialogue. This procedure is popular among MEPs who regularly pose questions. Outside of the Monetary Dialogue, the EP shall also be consulted before the members of the Executive Board are nominated; however, its opinion is not binding on the European Council, at least not legally. In case of disagreement, the EP may ask the Council to reconsider its nomination but the Council is by no means obliged to do so.

As far as the actual functioning of the Dialogue is concerned, despite the absence of any formal obligation, the ECB has indeed appeared before the EP four times per year. In fact, the ECB has been 'highly responsive to the ECON' (Eijffinger and Mujagic 2004, 190). However, the novelties and the changes in the ECB's role induced by the crisis, for example, in the form of its participation to the troika, have challenged the smooth functioning of the Dialogue (Belke 2014, 205).

By contrast, some have criticized the practice of the Dialogue, which puts its efficiency in the quest for more accountability into question. For instance, the President of the ECB was found to largely repeat what had already been said during the press conference that preceded the hearings before the EP committee (Claeys, Hallberg, and Tschekassin 2014, 7), which has led to a limited interest of the EU media in the Monetary Dialogues (Heidebrecht $2015,511)$. In fact, some have observed that the ECB monthly press conferences receive more attention than the Monetary Dialogue (Claeys, Hallberg, and Tschekassin 2014, 8). Additionally, MEPs long did not use this opportunity to ask the ECB about its actions, but rather focused on questions touching upon general economic questions (8) even though they receive briefings prepared by a monetary expert panel before each meeting.

The president of the ECB also commonly addresses these topics in his initial speech so that MEPs could and arguably should use the question and answer session that follows the president's statement to continue the dialogue on these specific issues (7). The publicly held Monetary Dialogue could furthermore be expected to engender transparency of the ECB vis-à-vis the market actors and the citizenry in general; however, there are no indications of this in practice. Admittedly, reports in all official languages are indeed prepared after each public meeting and the audio recordings of these same meetings are made available on the EP's website (Claeys, Hallberg, and Tschekassin 2014, 4). However, the ECB has little incentive to give important indications concerning its monetary policy when it goes to the EP, since there is a lack of attention from the media. This is a vicious circle, since the interest of the media is directly dependent on the importance of the information released during the Dialogue sessions (Heidebrecht 2015, 511-512). 
Furthermore, the difficulties for MEPs in exercising an effective control are certainly linked to the fact that the ECB's mandate, as defined in Article 127 TFEU, is rather vague, which makes their control, and hence effective accountability, uneasy. It simply defines that the objectives of the ESCB is to maintain price stability while'support[ing] the general economic policies in the Union with a view to contributing to the achievement of the objectives of the Union.'The ECB has recently assumed new functions, as financial market supervisor for example, and it could be led to resort to the new instrument of quantitative easing. Some have hence argued for the use of the Monetary Dialogues as a means to also control its actions in these frameworks. The Dialogue, however, would have to be reformed accordingly (Belke 2017, 28; Claeys, Hallberg, and Tschekassin 2014, 10) and it may appear too narrow to allow for the control of the ECB's operations at present.

Additionally, the ECB has long been not very transparent, which led MEPs to use the Monetary Dialogue as an opportunity to advocate for a more transparent ECB (Amtenbrink and van Duin 2009, 578f). Since 2015, MEPs have had an additional instrument to help them hold the ECB to account, as the minutes of the ECB Governing Council are now published (Belke 2017 , 8). Though they only entail an anonymous summary of the discussion which can be justified to prevent any adverse effects on the markets (Belke 2017), MEPs could now seize this opportunity to enter in a more content-based exchange with the ECB; whether they do so will have to be observed in the future.

Beyond all these shortcomings visible in practice, it remains that parliamentary involvement in the ECB's monetary policy is largely circumscribed. The Monetary Dialogue opens the possibility for MEPs to engage in a debate with the ECB's president on the Central Bank's yearly report. Additionally, the EP's ECON Committee hears the ECB president or members of the Executive Board four times per year, asks written questions and is consulted before the members of the Executive Board are appointed. These are hence largely soft and relatively harmless instruments, which were even more unlikely to lead to an effective control when the ECB was not very transparent as it was the case in the first years after its creation. National parliaments, despite their quality as co-guarantors of the democratic legitimacy within the EU together with the EP, are not involved in any way. This is particularly problematic, as the ECB's monetary policy directly impacts on the Member States' economic situations. Thus, the question can be asked whether the newly created Banking Dialogue could serve as a model to reform and improve the Monetary Dialogue.

\section{The newly introduced Banking Dialogue ${ }^{3}$}

The Banking Dialogue pertains to a newer evolution visible in the recent creation of the Banking Union after the financial crisis. As recalled in the introduction, the Banking Union architecture is built on three pillars: The Single Supervisory Mechanism (SSM), the Single Resolution Mechanism (SRM) and the European Deposit Insurance Scheme (EDIS). The Banking Dialogue exists in the framework of both the SSM and the SRM. With the establishment of the SSM, the ECB was conferred new powers. It now assumes competences of direct supervision of the most systemically important banks in the Eurozone. The National supervisory authorities, instead, continue to carry out the supervision of 'less significant banks', albeit under the ultimate responsibility of the ECB.

With the aim to ensure a separation between supervisory responsibilities and monetary policy, the ECB's supervisory tasks are carried out by a single-standing Supervisory Board. 
This Board is composed of a Chair, a Vice-Chair, four representatives of the ECB and one representative from each national supervisory authority in the participating Member States. The appointment of the Chair, the Vice-Chair and the four representatives of the ECB is submitted to the EP's approval which follows a public hearing of the candidates proposed by the ECB. We notice here already the difference between the consultative procedure that exists in the framework of the Monetary Dialogue and the binding one in place in the Banking Dialogue.

The Banking Dialogue takes place in an area that had thus far largely remained the responsibility of the Member States alone. Thus, this new transfer of powers may account for the need to involve not only the European Parliament, but also national parliaments even if, as highlighted below, their status does differ in the accountability procedures in place. Additionally, and perhaps primarily, the SSM is a mixed mechanism in which national and European institutions are called to intervene and cooperate. In this sense, it has been considered that'such direct possibility for national parliaments to call the ECB to account seems appropriate given the mixed administration created. It will often be the $E C B$, rather than the respective NCA [National Competent Authority], which decides on issues that may have a huge impact in the Member States' (Ter Kuile, Wissink, and Bovenschen 2015, 171).

The conferral upon the ECB of direct supervisory competences on the most systemically important banks -and indirect supervisory powers over the less significant credit institutionsimplies for some the need to counterbalance the ECB's independence with the introduction of appropriate democratic oversight mechanisms over the new European banking supervisor. On the one hand, the chances of a successful Banking Union project largely depend on the capacity of the ECB to endure the political and economic pressure, also from national governments and EU institutions. In this perspective, the legal clause (Art. 19 Reg. SSM) that recognizes the independence of the ECB and national authorities within the SSM is structured similarly to Article 130 TFEU concerning the ECB monetary policy (Macchia 2014, 117ff). On the other hand, the conferral of supervisory tasks draws the ECB into a potential space of politicization. As observed by the economic literature, the level of central bank independence is inversely proportionate to the number of objectives that characterize the central bank's mandate (Fodor 1994, 207ff) and the creation of the SSM has widened the ECB's mandate. Guaranteeing independence remains a crucial issue alongside the need to maintain appropriate accountability levels.

The political implications of the banking supervision hence demand appropriate parliamentary oversight channels and a robust democratic accountability framework (with the limitations already observed however). This is particularly the case of banking supervision at the supranational level and of the ECB, since it is amongst the most independent central banks worldwide. In this context, Article 21 of the SSM Regulation establishes that 'the ECB shall be accountable to the European Parliament and to the Council for the implementation of this Regulation.' In line with Article 10 Treaty of the European Union (TEU), the SSM Regulation considers the European Parliament and the Council as the two 'democratically legitimised institutions representing the citizens of the Union and the Member States' (recital no. 66). Given the focus of the present article on the interaction between the ECB and the $E P$, the Council's role will not be considered here. It is in any case interesting to note that the EP was conferred rights of information only after it had blocked the decision-making process with both Commission and the ECB (Schmidt 2016, 20). Some have even argued that 'in the case of the Banking Union, the EP managed to invent its own right to hold hearings for 
appointments to head new boards, mainly because the Commission and the ECB felt that they could not say no to this' (ibid). As indicated above, one of the specificities of the Banking Dialogue is that it involves both the EP and national parliaments; the framework for their involvement and the practice developed so far will be examined in turn.

The EP's oversight powers within the SSM are only partially defined by the SSM Regulation. Its Article 20(9) refers to an Interinstitutional Agreement between the EP and the ECB for the concrete definition of the 'practical modalities of the exercise of democratic accountability and scrutiny over the exercise of the tasks conferred on the ECB by this Regulation.' The Interinstitutional Agreement between the EP and ECB was approved and published in November 2013. Moreover, in December 2013, the Council of the EU and the ECB signed a Memorandum of Understanding on the cooperation related to the SSM. The Memorandum implemented the accountability and reporting obligation of the ECB to the Council and the Euro Group under the SSM Regulation.

The Interinstitutional Agreement between the EP and the ECB defined specific oversight procedures: (a) the presentation of an Annual Report of the ECB at a public hearing before the EP that addresses the execution of supervisory tasks within the SSM; (b) the power of the ECON Committee of the EP to convene the Chair of the Supervisory Board for ordinary hearings, ad hoc exchanges of views and confidential meetings; $(c)$ the duty of the ECB to reply in writing to written questions put to it by the EP as promptly as possible, and in any event within five weeks of their transmission to the ECB; and (d) the possibility for the EP to access some categories of information in possession of the ECB.

In an attempt to strengthen the standard of transparency in the selection process of the Chair and Vice-Chair of the Supervisory Board, the Interinstitutional Agreement also submitted their appointment to the EP's approval taken during a public hearing of the candidates proposed by the ECB. If the proposal for the Chair is not approved, the ECB may decide either to draw on the pool of candidates that originally applied for the position or to re-initiate the selection process. The EP has this veto power also in case of an ECB proposal to remove the Chair and the Vice-Chair of the Supervisory Board from their office. Moreover, if the EP sets up a Committee of Inquiry, the ECB shall assist the Committee of Inquiry in carrying out its tasks in accordance with the principle of sincere cooperation. In exchange for this support, the EP shall respect certain confidentiality obligations. Finally, according to the Interinstitutional Agreement, the ECB shall pre-emptively inform the ECON Committee about the main contents of some categories of acts that the ECB drafts for their adoption within the SSM. A similar obligation also exists with reference to the Code of Conduct in the SSM Regulation.

To a certain extent, the new powers of the EP within the Banking Union represent the partial reproduction and enhancement of the format already experimented with the Monetary Dialogue.

Practice shows that although the ordinary hearings that take place within the Banking Dialogue are less numerous than those organized as part of the Monetary Dialogue, if the ad hoc meetings are counted, then exchanges between the EP and the ECB in its quality as banking authority take place roughly at the same frequency. During 2015, the Chair of the Supervisory Board indeed spoke before the EP ECON Committee for the presentation of the 2014 ECB Annual Report on supervisory activities and she interacted with the EP ECON Committee in the occasion of two ordinary public hearings while two ad hoc exchanges of views were also organized. In 2016, the Chair of the Supervisory Board interacted in the 
occasion of two ordinary meetings with the EP ECON Committee as well as of three ad hoc exchanges of views. She was furthermore involved in the European Parliamentary Week $2016^{4}$ and again presented the Annual report on supervisory activities to the EP ECON Committee, whereas the Supervisory board vice-chair additionally gave a speech at a parliamentary evening on 13 September 2016. Despite similar frequency as in the Monetary Dialogue, the Banking Dialogue's contribution to the ECB's effective accountability could be more limited as it is characterised by high levels of secrecy (Curtin 2017). For what regards the content of these exchanges, recent research has shown that not all the questions posed by MEPs in fact regard banking supervision (Amtenbrink and Markakis 2017, 19ff). Others only partially concern this issue and the Chair of the Supervisory Board has thus far referred to this limitation to avoid providing any answer (20). MEPs pose informed questions though (21).

As in the Monetary Dialogue, the EP's new powers within the Banking Union are rarely configured as definitive and fully binding. Nonetheless, the new ex post parliamentary oversight capacities can potentially activate fruitful discourse dynamics to make the Banking Union governance more transparent, more open and consequently more legitimate. This Dialogue implies that the ECB maintains the 'last word' with regard to competences that already before their transfer to the EU level had in many Member States been taken away from the entitlement of democratically elected bodies (ECB 2017, 51).

The SSM interestingly also foresees certain accountability mechanisms of the ECB vis-à-vis national parliaments as had been requested by national parliaments themselves. The formalization of such type of relationships between both institutions is unique. This is because accountability is in general to be ensured at the same institutional level, i.e. EU institutions are to be accountable to other EU institutions, whereas national institutions are accountable to other national institutions (Zilioli 2016, 176). Recital 56 to the Regulation justifies this relationship with national parliaments as follows:'This role for national parliaments is appropriate given the potential impact that supervisory measures may have on public finances, credit institutions, their customers and employees, and the markets in the participating Member States.' One can, however, wonder if this impact is specific to the supervisory measures adopted in the framework of the SSM or if, on the contrary, and as we have already hinted to, the ECB's actions are likely to produce effects important enough on Member States that they would justify closer relationships between the Central Bank and national parliaments in all its domains of activity.

Despite there not being any formal framework for the relationships between national parliaments and the ECB in its monetary policy (Bovens and Curtin 2016, 210), some informal exchanges occurred before the adoption of the SSM Regulation (Jančić 2017, 152f). The relationships established by this regulation are therefore to be envisaged within the broader context of tighter relationships between the ECB and national parliaments. The provisions that concern national parliaments are separated from the ones on 'Accountability and reporting' that concern the EP and the Council. Even if national parliaments are addressed under the same Chapter, they are the subject of a different article simply titled 'National parliaments' without any further detail. This difference in treatment, whereby national parliaments are set in a secondary position, is more in line with the principle according to which EU institutions are to be accountable to EU (and not national) institutions than if they had been considered with the EP together. 
Additionally, national parliaments' involvement may endanger the Supervisory Board members' capacity to respect their obligation to act in the interests of the Union as a whole as requested by Article 26 of the SSM Regulation (Zilioli 2016, 176-177). Indeed, it is likely that the Board members will be called to their parliaments of nationality to avoid linguistic difficulties; however, it will be 'difficult [...for said Board member] to bear in mind the obligation of the Supervisory Board to take account of the interests of the Union as a whole in its decisions if they clearly conflict with the national interest' (ibid).

Similarly to the direct information channel between EU institutions and national parliaments foreseen by the Lisbon Treaty, the SSM Regulation establishes the direct transmission of the SSM annual report to national parliaments 'simultaneously' as it is forwarded to the European Parliament. In reaction,'[n] ational parliaments may address their reasoned observations to that report.' Moreover,

[n]ational parliaments of the participating Member States, through their own procedures, may request the ECB to reply in writing to any observations or questions submitted by them to the $E C B$ in respect of the tasks of the ECB under this Regulation.

In addition to this written procedure, face-to-face exchanges of view may be organized with the Chair or a member of the Supervisory Board 'in relation to the supervision of credit institutions in that Member State'. Note, however, that these prerogatives were only attributed to the national parliaments of the participating Member States. These provisions concerning national parliaments are less protective than those concerning the European Parliament and they did not fully satisfy them.

Regarding the practice of these instruments, it should be noted that the information available in the ECB's annual reports and on its website are rather scarce as opposed to the information concerning the interaction with the EP. Data obtained from the ECB shows that two of such exchanges of views took place each year in 2014, 2015 and 2016 involving the German Bundestag (Finance Committee), the French National Assembly (European Affairs Committee), the Dutch House of Representatives (Finance Committee), the Italian Senate (twice) (Treasury and Finance Committee) and the Slovenian National Assembly. In the German Bundestag, in the Dutch House of representatives and in the Italian Senate, the exchanges of views took place before sectoral specialized committees, i.e. the Finance Committee and the Treasury and Finance Committee. Some members of the finance committee may also be members of the European Affairs Committee: in France, for example, dual membership is mandatory. Nevertheless, it can be reasonably expected that the members of the European Affairs Committee are, in general, less capable of holding the ECB to account for its actions than the members of the other parliaments' sectoral committees. Hence, it is necessary to monitor the identity of the MPs who are to check on the ECB's actions to establish whether the accountability mechanisms are likely to be truly efficient or not.

\section{Conclusion: The Banking Dialogue as model for the reform of the Monetary Dialogue?}

As illustrated above, the SSM Regulation has established an original framework for the accountability of the ECB in its quality as supervisory authority in the Banking Union.

So far, national parliaments had not formally been included in the mechanisms designed to hold the ECB to account. Only the European Parliament had been involved. In the Banking Dialogue, national parliaments and the EP have arguably not been placed on an equal footing 
and it is the EP alone, together with the Council that shall ensure accountability. By contrast, national parliaments are 'only' to be informed and to be able to submit observations and questions as well as to organize hearings. Such difference is nevertheless justified given the attribution of this new competence to an EU institution, the ECB, and it contributes to fully clarifying the different institutional standing of the EP and national parliaments. These new accountability channels hence reinforce transparency - with the pitfalls highlighted above however - as they allow for parliamentary debates, and they contribute to enhanced legitimacy by formalizing the relationship between the ECB and national and European legislatures. Parliaments can rely on legally anchored mechanisms and are not dependent on the ECB's willingness to engage with them.

The Banking Dialogue could open new avenues in the ECB's and the EU's quest for reinforced democratic accountability (and hence legitimacy) in that it could represent a model to be reproduced in the framework of the Monetary Dialogue. One could for instance imagine that the ECB and national parliaments regularly interact on an informal basis. The same soft powers of the national parliaments in the Banking Dialogue could also be attributed to them in the monetary field. This would imply that they receive the Annual report from the ECB directly and may subsequently issue comments or questions and invite ECB representatives for exchanges of views.

In this way, the informational asymmetry sometimes observable between parliaments and governments, as well as among parliaments themselves would be avoided. Thereby, the only obstacle to further parliamentary scrutiny would be national parliaments' own lack of mobilization and not the absence of any clearly defined framework as is currently the case. At a time when the ECB's policy in this framework is sometimes doubted -which gives rise to increased problems of democratic legitimacy- perhaps one way to remedy to these issues would indeed be to enhance throughput legitimacy by systematically involving national parliaments. This would indeed clearly reinforce the'awareness, publicity and understanding of EU monetary policy' (Jančić 2017, 154). Admittedly, monetary policy is a competence that has been transferred to the EU level. However, it remains that the ECB's decisions in this field have a serious and direct impact on the Member States (in particular since the ECB's competences have been largely stretched) and thus exchanges between the ECB and national parliaments should also be organized in this domain. Such an evolution would not threaten the ECB's independence since no procedure is ever binding.

National parliaments very regularly hold hearings with Commissioners and Commission officials in the framework of the Political Dialogue without there being any legal basis for these interactions. One could easily imagine that a similar practice is developed between the $E C B$, in its quality as monetary authority, and national parliaments. This would be welcome at a time when the ECB's powers have been undoubtedly stretched and may still increase in the future. An important risk would, however, remain, since in the absence of any formal obligation, the ECB is free to choose which parliaments it decides to visit -just like the European Commission is free in its choice to visit one parliamentary chamber or another in the framework of its Political Dialogue. Therefore, while a certain degree of formalization appears desirable, it does not necessarily have to take the form of a Treaty revision.

On the other hand, the EP has also seen its position improved in the framework of the Banking Dialogue with respect to the one it had been attributed in the older Monetary Dialogue. Its involvement within the appointment procedure of the Supervisory Board Chair is not limited to a sole consultation, as its opinion is binding on the ECB. This procedure 
could offer a model for a stronger parliamentarization of the ECB's Executive Board appointment procedure, which in turn could contribute to the enhancement of the ECB's legitimacy. Additionally, while the Monetary Dialogue concerns an area in which the ECB's mission is not precisely defined, its tasks as banking supervisor are easier to trace and hence to control for MEPs. This will hopefully incentivize them to engage in a more detailed dialogue with the ECB. In turn, this evolution will hopefully have a spill over effect on the Monetary Dialogue, which would consequently continue to become more focused instead of addressing topics of general interest. In sum, all these developments would contribute to enhance democratic legitimacy in allowing European and national parliaments to become more involved thereby promoting better transparency vis-à-vis European citizens.

\section{Notes}

1. See also Table 1.

2. This argument is owed to Napoleon Xanthoulis.

3. See also Table 1.

4. https://www.bankingsupervision.europa.eu/press/speeches/date/2016/html/index.en.html.

\section{Disclosure statement}

No potential conflict of interest was reported by the authors.

\section{References}

Amtenbrink, F. 1999. The Democratic Accountability of Central Banks. A Comparative Study of the European Central Bank. Oxford: Hart.

Amtenbrink, F. 2012. "Towards an Index of Accountability for Informal International Lawmakers?" In Informal International Lawmaking, edited by J. Pauwelyn, R. A. Wessel and J. Wouters, 337-355. Oxford: Oxford University Press.

Amtenbrink, F., and M. Markakis. 2017. "Towards a Meaningful Prudential Supervision Dialogue in the Euro Area? A Study of the Interaction Between the European Parliament and the European Central Bank in the Single Supervisory Mechanism." ADEMU, Working Paper 2017/079.

Amtenbrink, F., and K. van Duin. 2009. "The European Central Bank before the European Parliament: Theory and Practice After Ten Years of Monetary Dialogue." European Law Review 34 (4): 561-583.

Belke, A. 2014. "Monetary Dialogue 2009-2014: Looking Backward, Looking Forward." Intereconomics 4: 204-210.

Belke, A. 2017. "Central Bank Communication: Managing Expectations through the Monetary Dialogue." ROME Discussion Paper Series 17-04.

Beukers, T. 2015. “Constitutional Changes in Euro Government and the Relationship Between the ECB and the Executive Power in the Union." In What Form of Government for the European Union and the Eurozone? edited by F. Fabbrini, E. Hirsch Ballin, and H. Somsen, 95-110. Oxford: Hart.

Bovens, M. 2007. "New Forms of Accountability and EU-Governance." Comparative European Politics 5 (1): 104-120.

Bovens, M., and D. Curtin. 2016. "An Unholy Trinity of EU Presidents? Political Accountability of EU Executive Power." In The End of the Eurocrats' Dream - Adjusting to European Diversity, edited by D. Chalmers, M. Jachtenfuchs and C. Joerges, 190-217. Cambridge: Cambridge University Press.

Cafaro, S. 2017. "How the ECB Reinterpreted Its Mandate During the Euro-Crisis (and Why It Was Right in Doing So)." In Democracy in the EMU in the Aftermath of the Crisis, edited by L. Daniele, P. Simone and R. Cisotta, 217-233. Heidelberg: Springer-Giapichelli.

Claeys, G., M. Hallberg, and O. Tschekassin. 2014. “European Central Bank Accountability: How the Monetary Dialogue Could Evolve." Bruegel Policy Contribution 2014/04. 
Collignon, S. 2014. "Central Bank Accountability in Times of Crisis. The Monetary Dialogue: 2009-2014". Note for the European Parliament's Committee on Economic and Monetary Affairs, PE 507.482.

Curtin, D. 2017. 'Accountable Independence' of the European Central Bank: Seeing the Logics of Transparency." European Law Journal 23 (1-2): 28-44.

ECB. 2017. Annual Report on Supervisory Authorities 2016.

Eijffinger, S. C. W., and E. Mujagic. 2004. "An Assessment of the Effectiveness of the Monetary Dialogue on the ECB's Accountability and Transparency: A Qualitative Approach."Intereconomics 39 (4): 190-203.

European Commission. 2017. Communication on Completing the Banking Union. COM(2017) 592 final. European Parliament. 1990. Resolution on Economic and Monetary Union [1990]. OJ C284/62.

Fodor, G. 1994. "Sull'autonomia della banche centrali."In L'Italia e l'Europa oltre Maastricht (Supplemento a Economia e Banca, 7-8/1994-1995), edited by L. Bosco, R. Tamborini, and F. Targetti, 207-215.

Gormley, L., and J. De Haan. 1996. "The Democratic Deficit of the European Central Bank." European Law Review 21 (2): 95-112.

Heidebrecht, S. 2015. "Wie transparent ist die Europäische Zentralbank? Eine international vergleichende Betrachtung vor dem Hintergrund der weitreichenden Neuerungen zum Januar 2015." Zeitschrift für Politikwissenschaft 25 (4): 501-525.

Hinarejos, A. 2015. "Gauweiler and the Outright Monetary Transactions Programme: The Mandate of the European Central Bank and the Changing Nature of Economic and Monetary Union." European Constitutional Law Review 11 (3): 563-576.

Jančić, D. 2017. "Accountability of the European Central Bank in a Deepening Economic and Monetary Union." In National Parliaments after the Lisbon Treaty and the Euro Crisis: Resilience or Resignation?, edited by D. Jančić, 141-158. Oxford: Oxford University Press.

Macchia, M. 2014. "The Independence Status of the Supervisory Board and of the Single Resolution Board: An Expansive Claim of Autonomy?" In Towards the European Banking Union. Achievemnts and Open Problems, edited by E. Barucci and M. Messori, 117-129. Bagno a Ripoli: Passigli.

Magnette, P. 2000. "Towards 'accountable independence'? Parliamentary Controls of the European Central Bank and the Rise of a New Democratic Model" European Law Journal 6 (4): 326-340.

Roth, F., D. Gros, and F. D. Nowak-Lehmann. 2014. "Crisis and Citizens'Trust in the European Central Bank - Panel Data Evidence for the Euro Area, 1999-2012." Journal of European Integration 36 (3): 303-320.

Schmidt, V. A. 2016. "The 'New' EU Governance: 'New' Intergovernmentalism versus "New" Supranationalism Plus 'New' Parliamentarism." Cahiers du CEVIPOL Brussels Working Papers, 5/2016 (Issue on the EU economic governance), 7-31.

Schmitt, C. 1958. Die neutralen Größen im heutigen Verfassungsstaat, in Das Problem der innerpolitischen Neutralität des Staates, now in Verfassungrechtliche Aufsätze aus den Jahren 1924-1954. Berlin: Duncker \& Humblot, $41 \mathrm{ff}$.

Ter Kuile, G., L. Wissink, and W. Bovenschen. 2015. "Tailor Made Accountability Within the Single Supervisory Mechanism." Common Market Law Review 52 (1): 155-189.

Thiele, A. 2017. "The Independence of the ECB. Justification, Limitations and Possible Theats." ADEMU Working Paper 2017/079, Forthcoming.

Zilioli, C. 2016. "The Independence of the European Central Bank and its New Banking Supervisory Competences." In Independence and Legitimacy in the Institutional System of the European Union, edited by D. Ritleng, 125-179. Oxford: Oxford University Press.

Zilioli, C., and M. Selmayr. 2001. The Law of the European Central Bank. Oxford: Hart Publishing. 